\title{
Penyuluhan Tentang Demam Berdarah (DBD) dan Tanaman Pengusir Nyamuk Di Lingkungan Kecamatan Manggala Kota Makassar
}

\author{
Muawanah $^{* 1}$, St. Mu'tamirah ${ }^{2}$,Tuty Widyanti ${ }^{3}$ \\ ${ }^{1,3}$ Teknologi Laboratorium Medis, Politeknik Kesehatan Muhammadiyah \\ ${ }^{2}$ Sanitasi, Politeknik Kesehatan Muhammadiyah \\ *E-mail: ummi.ahsan79@gmail.com
}

\begin{abstract}
Manggala District is one of the sub-districts in Makassar City which often faces cases of Dengue Fever. Dengue fever is a disease transmitted through the bite of the Aedes aegypti mosquito. The breeding of Aedes Aegypti is increasing due to the increasingly crowded conditions of buildings and housing. These mosquitoes not only live in dirty water environments, but also in clean water such as bathtubs, water reservoirs, and others. Some community members still have limited knowledge and understanding of effective ways of dealing with dengue cases, as well as the use of plant species that can be used to repel mosquitoes. The purpose of the service is to increase the knowledge and understanding of the community about dengue fever and the use of mosquito repellent plants. The extension method is the presentation by the extension team, the discussion stage, and the evaluation stage. The results show an increase in public knowledge and understanding of dengue disease and the use of mosquito repellent plants. The conclusion is that the community finally knows the dangers of dengue disease and knows the types of mosquito repellent plants.
\end{abstract}

Keywords: Counseling, Dengue Fever, Aedes aegypti mosquito, mosquito repellent plants

\begin{abstract}
Abstrak
Kecamatan Manggala merupakan salah satu kecamatan di Kota Makassar yang sering menghadapi kasus penyakit Demam Berdarah (DBD). Penyakit DBD merupakan penyakit ditularkan melalui gigitan nyamuk Aedes Aegypti. Perkembangbiakan Aedes Aegypti semakin meningkat karena kondisi bangunan dan perumahan yang semakin padat. Nyamuk tersebut tidak hanya hidup dilingkungan air kotor, tetapi juga pada air bersih seperi bak mandi, tempat penampungan air, dan lain-lain. Sebagian Warga masyarakat masih memiliki keterbatasan pengetahuan dan pemahaman terhadap cara yang efektif dalam penanggulangan kasus DBD tersebut, serta pemanfaatan jenis tanaman yang bisa digunakan untuk mengusir nyamuk. Tujuan pengabdian adalah untuk meningkatkan pengetahuan dan pemahaman warga masyarakat tentang penyakit Demam Berdarah dan pemanfaatan tanaman pengusir nyamuk. Metode penyuluhan yaitu presentasi oleh tim penyuluh, tahap diskusi, serta tahap evaluasi. Hasilnya menunjukkan meningkatnya pengetahuan dan pemahaman masyarakat tentang penyakit DBD dan pemanfaatan tanaman pengusir nyamuk. Kesimpulannya bahwa masyarakat akhirnya mengetahui bahaya dari penyakit DBD serta mengenal jenis tanaman pengusir nyamuk.
\end{abstract}

Kata kunci: Penyuluhan, Demam Berdarah (DBD), Nyamuk Aedes Aegypti, tanaman pengusir nyamuk.

\section{PENDAHULUAN}

Demam Berdarah Dengue (DBD) merupakan salah satu penyakit yang disebabkan oleh virus dimana sudah banyak terjadi diseluruh dunia terutama di Negara-negara tropis. Penyakit DBD ini adalah penyakit infeksi oleh virus dengue yang disebabkan oleh penularan gigitan nyamuk Aedes Aegypti (Setiyawan, dkk. 2019). Gejala umum penyakit DBD ini adalah disertai dengan demam tinggi tiba-tiba, terjadi pendarahan dan menimbulkan shock bahkan kematian (Ulfa, dkk. 2019). Di Indonesia, penyakit tersebut masih merupakan masalah kesehatan yang cukup besar sampai saat ini. Kementerian Kesehatan RI memperoleh data mengenai kasus Demam Berdarah Dengue di Indonesia dalam satun tahun mencapai 95.893 kasus dengan jumlah 661 orang yang meninggal dunia (Liputan6.com, 2020). 
Menurut Dinas Kesehatan Kota Makassar, di Sulawesi Selatan mengalami peningkatan kasus Demam Berdarah Dengue per bulan Februari tahun 2020 yaitu terdapat 65 kasus DBD. Dari 65 kasus tersebut, Kecamatan Manggala menjadi daerah yang paling banyak terjangkit DBD dan umumnya penderita DBD merupakan kalangan anak-anak dan remaja (Kompas.com, 2020). Hal ini disebabkan karena kondisi lingkungan Kecamatan Manggala yang merupakan salah satu kecamatan dengan jumlah kepadatan penduduk yang tinggi dan bentuk perumahan yang saling berdekatan. Selain itu, pengetahuan, sikap, dan prilaku masyarakat terhadap pencegahan penyakit DBD dan pemahaman terhadap tanaman pengusir nyamuk masih minim.

Seperti kita ketahui bersama bahwa vektor utama penyakit DBD di Indonesia adalah nyamuk Aedes Aegypti. Nyamuk ini menyukai tempat yang terdapat genangan air bersih, dan tidak kontak langsung dengan tanah sebagai tempat perindukannya (Hendra dan Mila, 2004 dalam Sahamastuti dkk, 2019). Seperti tempat penampungan air misalnya drum, bak mandi. Selain itu tempat penampungan air alamiah seperti lubang pohon, lubang batu, ataupun bukan tempat penampungan air seperi botol bekas, vas bunga, ban bekas, dan sebagainya. Nyamuk Aedes Aegypti ini juga berkembang pesat apabila curah hujan yang tinggi karena terjadi banyak muncul genangan air.

Depatemen Kesehatan telah melakukan berbagai langkah dalam upaya pencegahan DBD, dimana titik fokus pencegahannya adalah dengan pemutusan rantai penularan yang terdiri dari virus, nyamuk Aedes Aegypti, dan manusia. Hal itu disebabkan karena belum ditemukannya vaksin dan obat untuk mencegah dan mengobati penyakit DBD yang efektif (WHO, 2004 dalam Vitaningtyas, 2019). Pencegahan DBD dapat dilakukan dengan motto $3 \mathrm{M}$ plus yaitu Menguras, Menutup tempat penampungan air, dan Memanfaatkan kembali barang bekas atau mendaur ulang (Mulyani dkk, 2013). Sedangkan kegiatan plus yaitu hindari nyamuk di pagi dan sore hari dengan menggunakan obat anti nyamuk oles, menggunakan kelambu tidur, pemeliharaan ikan pemangsa jentik nyamuk, penanaman tanaman pengusir nyamuk, penaburan bubuk larvasida pada tempat penampungan air, pengaturan cahaya dan ventilasi dalam rumah, dan tidak menggantung pakaian dalam rumah (Suharmiati, 2007 dalam Sahamastuti dkk, 2019).

Sekarang ini, upaya pengendalian nyamuk Aedes Aegypti lebih banyak dilakukan oleh masyarakat secara kimiawi dengan menggunakan insektisida sintetis karena bekerja lebih efektif dan hasilnya lebih cepat bila dibandingkan dengan pengendalian biologis. Akan tetapi insektisida sintetis ini dapat memberikan dampak buruk yaitu mengakibatkan keracunan pada manusia, hewan, lingkungan dan serangga menjadi resisten (Kardinan, 2003 dalam Mulyani, dkk. 2013).

Masalah-masalah tersebut dapat diatasi dengan penggunaan bahan alami dari tanaman. Tanaman memiliki kandungan metabolit sekunder yang terdiri dari beribu-ribu senyawa bioaktif seperti saponin, tannin, flavonoid, alkaloid, dan minyak atsiri yang berfungsi sebagai insektisida yang digunakan untuk mengendalikan organisme pengganggu tanaman seperti serangga di lingkungan rumah (Price dan Price, 1997 dalam Mulyani, dkk. 2013). Adapun beberapa tanaman yang dijadikan sebagai bahan baku untuk pembuatan produk obat nyamuk yang beredar di pasar seperti bunga lavender, biji kecubung, kulit jeruk, daun sirih, daun sereh, bunga tapak dara, jahe, kenanga, dan cengkeh. Selain tanaman itu diolah untuk menjadi produk obat nyamuk yang dioleskan di kulit seperti lotion, tanaman tersebut juga dapat digunakan secara langsung misalnya dengan hanya meremas-remas daun atau bunganya yang kemudian dioleskan ke kulit agar terhindar dari gigitan nyamuk. Di samping adapula tanaman yang harus melalui proses destilasi untuk menghasilkan minyak atsiri (Setiyawan dkk, 2019).

Oleh karena itu melalui kegiatan pengabdian kepada masyarakat dilakukan penyuluhan kesehatan dengan judul penyuluhan tentang Demam Berdarah Dengue (DBD) dan tanaman pengusir nyamuk di lingkungan Kecamatan Manggala Kota Makassar.

Berdasarkan tingkat kebutuhan masyarakat terhadap kesadaran dalam menerapkan kebersihan lingkungan dan kondisi masyarakat yang masih minim akan pemahaman terhadap penyakit DBD dan kurangnya pengetahuan tentang tanaman pengusir nyamuk, maka program Pengabdian Kepada Masyarakat melalui Penyuluhan Kesehatan diharapkan kepada masyarakat Kecamatan Manggala Kota Makassar dapat lebih memperhatikan lingkungan dengan selalu menjaga kebersihan agar dapat mencegah terjadinya penyebaran nyamuk Demam Berdarah Dengue Aedes Aegypti di masa yang akan datang. Selain itu masyarakat diharapkan lebih mengenal berbagai jenis tanaman pengusir nyamuk yang 
sering ditemukan di lingkungan rumah dan bahkan sering digunakan oleh masyarakat untuk keperluan sehari-hari.

\section{METODE}

Kegiatan pengabdian telah dilaksanakan pada bulan Maret 2021 di Kecamatan Manggala Kota Makassar dan diikuti oleh 30 peserta yang merupakan warga masyarakat. Metode pelaksanaan pengabdian kepada masyarakat telah dilakukan sesuai dengan protokoler kesehatan di masa pandemi ini. Adapun langkah-langkah kegiatan yang telah dirancang sebelumnya yaitu:

a. Studi pendahuluan dengan melakukan observasi meliputi survey dan perizinan serta penyiapan sarana dan prasarana yang dibutuhkan pada saat penyuluhan.

b. Warga masyarakat diundang untuk datang ke balai desa sesuai dengan waktu yang telah ditetapkan atas kesepakatan bersama dengan pemerintah desa setempat dengan himbauan mengikuti protokoler kesehatan seperti menggunakan masker dan menjaga jarak.

c. Tahap penyuluhan yang dilaksanakan dengan pemaparan materi penyuluhan yang bertujuan untuk memberikan informasi tentang Demam Berdarah (DBD) dan tanaman pengusir nyamuk.

d. Tahap akhir yaitu diskusi dengan Tanya Jawab dari penjelasan materi penyuluhan.

Metode pelaksanaan dalam kegiatan ini berdasarkan dari survei kondisi dan keadaan permasalahan mitra masyarakat, serta SDM yang terdapat di Kecamatan Manggala Kota Makassar.

\section{HASIL DAN PEMBAHASAN}

Pengabdian kepada masyarakat merupakan suatu kegiatan untuk mempromosikan kesehatan dalam peningkatan kualitas kesehatan masyarakat melalui penyuluhan kesehatan di Kecamatan Manggala Kota Makassar. Kegiatan pengabdian ini dilakukan dengan tetap mengikuti protokoler kesehatan yaitu 3M (mencuci tangan, memakai masker, dan menjaga jarak). Oleh karena itu penyuluhan kesehatan dilaksanakan di dalam Mesjid dimana peserta penyuluhan yang hadir merupakan jamaah masjid. Selain itu jumlah peserta penyuluhan dibatasi jumlahnya yang disesuaikan dengan kondisi masjid tersebut.

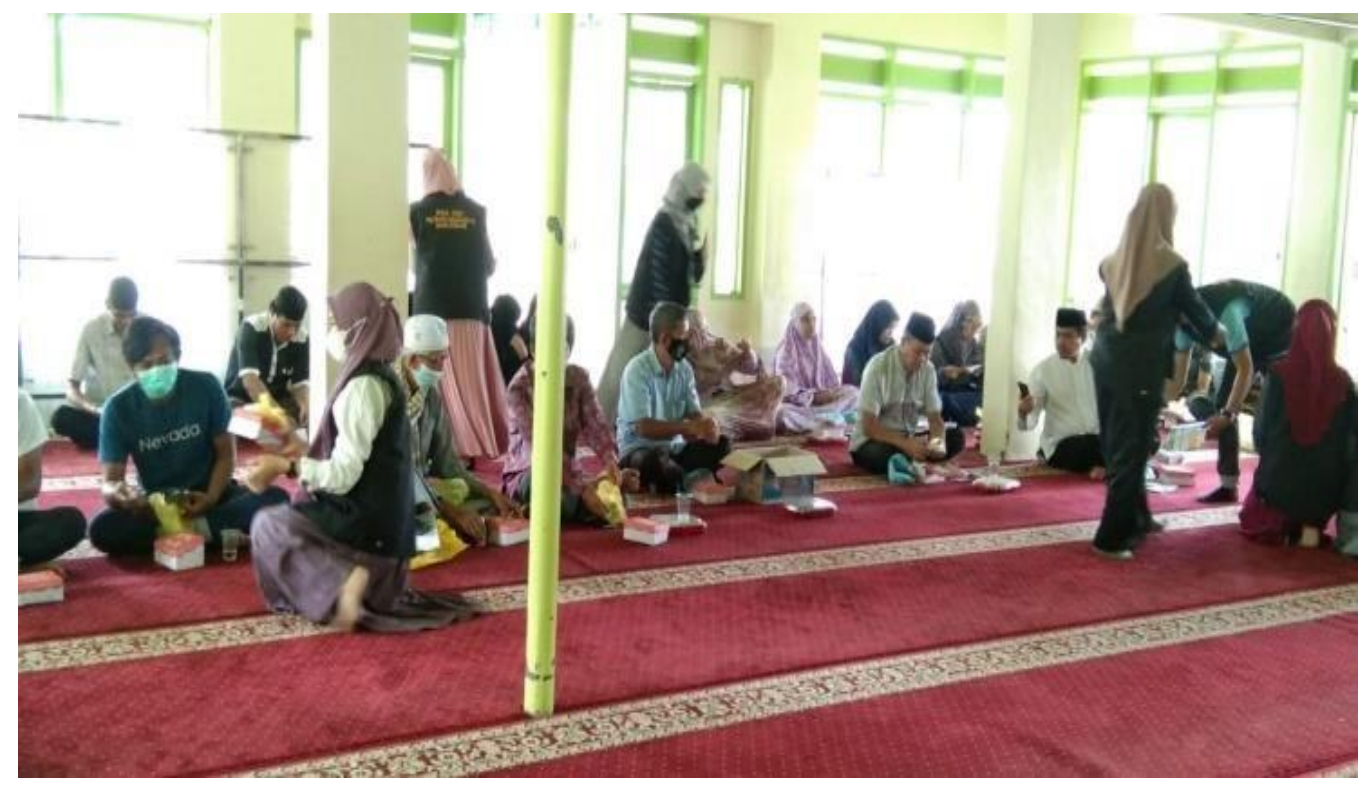

Gambar 1. Peserta Penyuluhan

Penyuluhan tentang Demam Berdarah dan tanaman pengusir nyamuk dilaksanakan dengan metode ceramah untuk menyampaikan informasi kepada Masyarakat tentang perkembangbiakan nyamuk Aedes aegypti, gejala penyakit DBD dan pencegahannya, serta pemanfaatan berbagai jenis tanaman yang bisa digunakan untuk mengusir nyamuk seperti bunga lavender, biji kecubung, kulit jeruk, daun sirih, daun sereh, bunga tapak dara, jahe, kenanga, dan cengkeh. Tanaman tersebut telah dijadikan 
sebagai bahan baku pembuatan produk nyamuk. Para peserta penyuluhan sangat berperan aktif dalam menyimak penyajian materi oleh tim karena masyarakat Kecamatan Manggala menghadapi kasus DBD setiap tahunnya. Oleh karena itu, mereka merasa perlu untuk diberikan pengetahuan tentang hal tersebut.

Selain itu, kegiatan penyuluhan ini juga menyampaikan kepada masyarakat untuk meningkatkan kesadaran selalu menjaga kebersihan lingkungan sekitar tempat tinggalnya, dan terlibat secara langsung dan aktif untuk melakukan kegiatan-kegiatan kesehatan untuk mewujudkan tingkat kesehatan yang maksimal seper dilakukan motto 3M plus yaitu Menguras, Menutup tempat penampungan air, dan Memanfaatkan kembali barang bekas atau mendaur ulang). Adapun salah satu kegiatan plus yaitu pemanfaatan tanaman pengusir nyamuk.

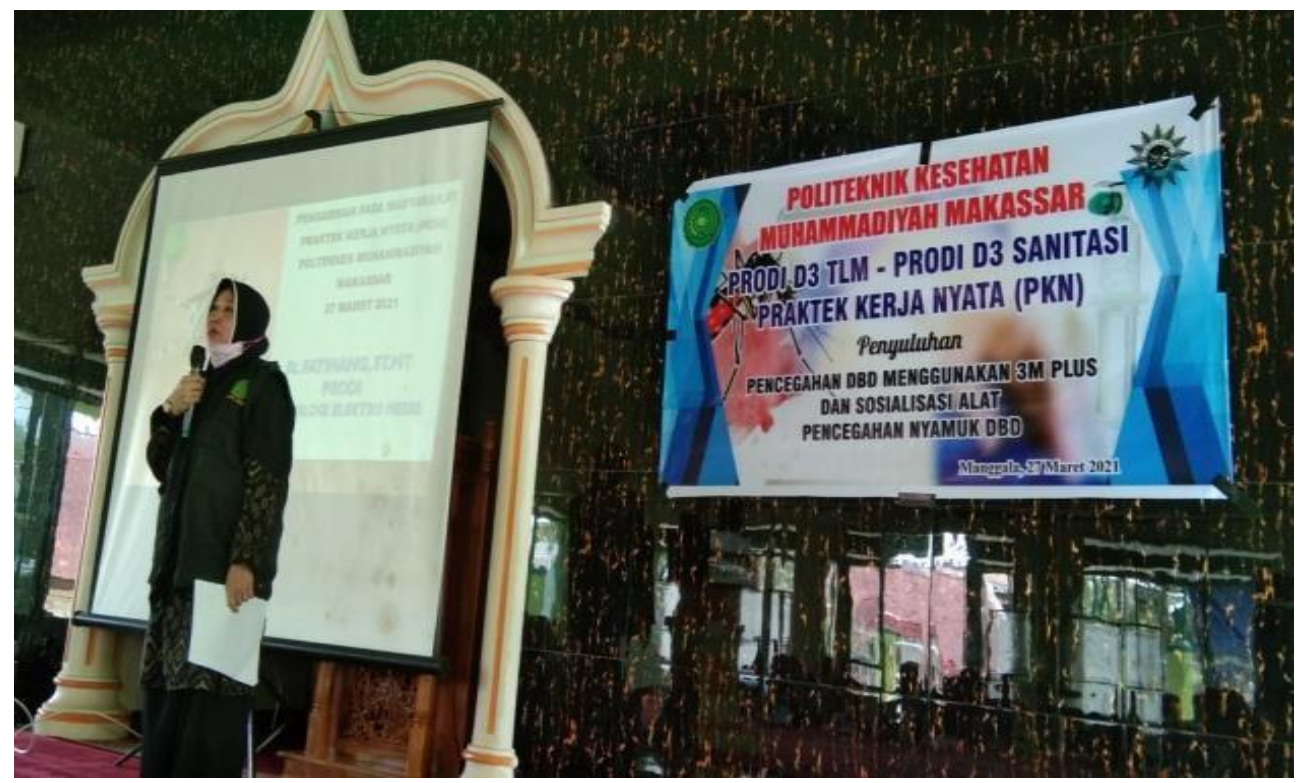

Gambar 2. Penyampaian Materi Penyuluhan

Warga sangat antusias menyimak dan mendengarkan materi penyuluhan tersebut dan akhirnya mereka memperoleh pengetahuan dan informasi tentang penyakit DBD dan pemanfaatan tanaman pengusir nyamuk. Warga masyarakat Kecamatan Manggala Kota Makassar menyadari dan memahami bahwa memelihara kebersihan lingkungan disekitar kita yang dimulai dari lingkungan rumah tangga sangatlah penting untuk meningkatkan derajat kesehatan masyarakat.

Adapun tahap akhir dari kegiatan penyuluhan ini yaitu kegiatan diskusi melalui tanya jawab tentang materi penyuluhan yang telah disampaikan. Adapun melihat jumlah pertanyaan yang diberikan oleh peserta penyuluhan cukup banyak, maka hal itu menunjukkan respon yang sangat positif dan rasa keingintahuan yang sangat tinggi dari warga masyarakat.

Berdasarkan wawancara dan pengamatan langsung selama kegiatan, maka kegiatan pengabdian pada masyarakat Kecamatan Manggala Kota Makassar ini memberikan hasil yang sesuai dengan harapan yaitu meningkatnya pengetahuan dan pemahaman masyarakat tentang penyakit DBD serta pencegahannya, serta pemanfaatan tanaman pengusir nyamuk sebagai upaya pengendalian secara biologi terhadap penyakit DBD.

Adapun harapan warga masyarakat Kecamatan Manggala adalah dapat dilakukan penyuluhan kesehatan dalam lingkungan masyarakat secara umum sesering mungkin dan secara kontinyu, dan khususnya penyuluhan tentang pencegahan DBD dan didukung dengan sosialisasi pengunaan alat pencegahan DBD sesuai dengan kemajuan teknologi. 


\section{KESIMPULAN}

Dari kegiatan penyuluhan pada pengabdian masyarakat ini dapat memberikan kesimpulan bahwa pengetahuan dan pemahaman masyarakat tentang penyakit Demam Berdarah Dengue (DBD) serta pencegahannya semakin meningkat, serta masyarakat lebih mengetahui dan mengenal tentang pemanfaatan tanaman pengusir nyamuk sebagai upaya pengendalian secara biologi terhadap penyakit DBD.

\section{PERSANTUNAN}

Penulis mengucapkan terimakasih kepada Direktur, Lembaga Penelitian dan Pengabdian Masyarakat (LPPM), dan Kaprodi D3 Teknologi Laboratorium Medis Poltekkes Muhammadiyah Makassar, atas dukungan dan kesempatan yang diberikan untuk melaksanakan pengabdian kepada masyarakat serta bantuan finansial dalam proses penyelenggaraan, serta para mahasiswa yang telah ikut membantu dalam pelaksanaan kegiatan ini..

Terima kasih kepada Pemerintah Kecamatan Manggala Kota Makassar khususnya Pimpinan dan para jamaah Mesjid Al-Mutaqqin Kecamatan Manggala yang memberikan kemudahan, kesediaan meluangkan waktu dan pesediaan sarana dan prasarana dalam pelaksanaan kegiatan pengabdian pada masyarakat sehingga dapat terlaksana dengan baik dan lancar.

\section{REFERENSI}

Kompas.com. 2020. 65 Kasus DBD di Makassar, Kecamatan Manggala Paling BanyakTerjangkit.https://regional.kompas.com/read/2020/03/17/22170931/65-kasus-dbd-dimakassar-kecamatan-manggala-paling-banyak-terjangkit. Diunduh tanggal 30 Mei 2021.

Liputan6.com. 2020. Kemenkes: Ada 95.893 Kasus DBD di Indonesia sepanjang 2020.https://www.liputan6.com/health/read/4425271/kemenkes-ada-95893-kasus-dbd-diindonesia-sepanjang-2020. Diunduh tanggal 30 Mei 2021.

Mulyani S, Mulyaningsih B, Lestari A.W, Ana F, Anna D,S. 2013. Insence Combustible Sereh, Cengkeh, dan Jeruk Sebagai Penolak Nyamuk Aedes Aegypti. Traditional Medicine Journal. Vol. 18(3), p 195-200. ISSN: 1410-5918. Universitas Gadjah Mada, Yogyakarta.

Setiyawan H, Lestari, A.S, Ayungnityas, E.N, Meradji, A, Diana, E, Utami, E.B. 2019. Penyuluhan Demam Berdarah Dengue (DBD) dan Tanaman Pengusir Nyamuk di Desa Modalan Banguntapan. Jurnal Pemberdayaan: Publikasi Hasil Pengabdian kepada Masyarakat.ISSN: 2580-2569; e-ISSN: 2656-0542. Vol. 3 No. 2, Hal: 241-244. Polteknik Kesehatan Bhakti Setya Indonesia, Bantul, Yogyakarta.

Sahamastuti A. T, Siratan E, Leonard T, E, Tjugianto G, E, Hartiadi L, Y, Agusta I. 2019. Penyuluhan dan Workshop Obat Nyamuk Sintetis dan Alami Sebagai Tindakan Pencegahan DBD. Jurnal Pengabdian dan Pemberdayaan Masyarakat. ISSN: 2549-8347 (online), ISSN: 2579-9126. Vol. 3 No. 2. Fakultas Bio Sains. Indonesia International Institute For Life Science. Jakarta Timur.

Ulfa A.M, Narista N, Sobirin. 2019. Penyuluhan Penyakit Demam Berdarah Dengue (DBD) di Puskesmas Gadingredjo Pringsewu. Jurnal Pengabdian Farmasi Malahayati. Vol. 2 No. 2. Program Studi Farmasi Universitas Malahayati.

Vitaningtyas Y, Agustiningrum M, Shella, Prisilia C, Putri C, E. 2019. Pengolahan Serai Sebagai Tanaman Obat Pengusir Nyamuk Bersama Anak-Anak di Pemukiman Pemulung Blok O Yogyakarta. ABDIMAS Altruis Jurnal Pengabdian Kepada Masyarakat. Vol. 2 No. 1. e-ISSN: 2620-5513. P-ISSN:2620-5505. Universitas Sanata Dharma. Yogyakarta 